Preprints of the

Max Planck Institute for

Research on Collective Goods

Bonn 2008/46

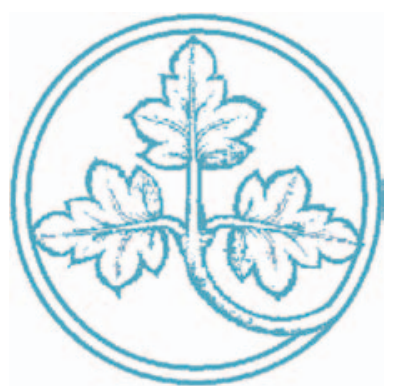

The Underpricing of Initial Public Offerings in Imperial Germany, 1870-1896

Carsten Burhop

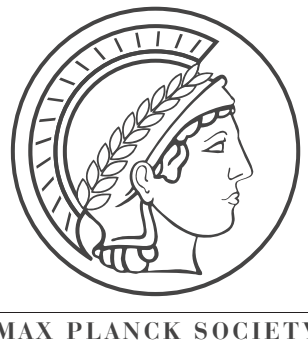




\section{The Underpricing of Initial Public Offerings in Imperial Germany, 1870-1896}

Carsten Burhop

December 2008 


\title{
The Underpricing of Initial Public Offerings in Imperial Germany, 1870-1896*
}

\author{
Carsten Burhop ${ }^{\ddagger}$
}

\begin{abstract}
In this article, we evaluate underpricing of initial public offerings (IPOs) at the Berlin Stock Exchange between 1870 and 1896. In contrast to modern data, first day returns were extraordinary low and averaged less than five percent, even during the speculative period of the early 1870s. Moreover, standard underpricing theories based on asymmetric information, signalling mechanisms, or litigation risk cannot explain underpricing. In contrast to modern markets, the past market return had a negative influence on initial returns. Finally, we show that cash-flow relevant information contained in the corporate charter were readily factored in the first market price. Thus, the historical capital market differed from today's market, but seems to have been efficient.
\end{abstract}

JEL-Classification: N 23; N 43; G 18

Keywords: Initial public offerings; Financial history; Germany pre-1913

* I would like to thank Christoph Engel, Hendrik Hakenes, Martin Hellwig, Thorsten Lübbers, Ivo Welch, Guntram Wolff, and participants in the Economic Research Seminar at the University of Münster, the Research Seminar at the Max-Planck-Institute for Research on Collective Goods, the Annual Meeting 2006 of the Wirtschaftshistorische Ausschuß of the Verein für Socialpolitik, the Annual Meeting 2006 of the Verein für Socialpolitik, the 2007 Annual Conference of the Economic History Society, the 2007 BETA-CNRS Workshop on Financial History, and 2008 World Congress of Cliometrics. The support of Marina Boland, Annika Petersen, and Brian Cooper is gratefully acknowledged. All remaining errors are the sole responsibility of the author.

¥ Max Planck Institute for Research on Collective Goods, Kurt-Schumacher-Straße 10, 53113 Bonn, Germany, Email: burhop@coll.mpg.de 


\section{Introduction}

Positive first-day returns of initial public offerings (IPOs) are a stylized fact of modern securities markets. They were, for example, reported for the U.S. (Ritter and Welch, 2002), the U.K. (Derrien and Kecskes, 2007), Germany (Ljungqvist, 1997), Japan (Isobe et al., 1998), and France (Biais et al., 2002). During the last three decades, mean underpricing was substantial, averaging about 15 percent in the U.S., Germany, and France. Thus issuers left a large amount of money on the table and thereby increased the cost of equity finance for them. Not only the occurrence of positive mean initial returns, but also the fluctuations of initial returns over time are noteworthy. First-day returns of IPOs averaged, for example, more than 50 percent in the internet bubble of the late 1990s, but below ten percent in the early 1990s. Beyond short-run fluctuations, we have some evidence of a secular trend in the size of initial returns. In particular, Chambers and Dimson (2008), Tinic (1988), and Simon (1989) showed that mean underpricing was less than ten percent during the roaring twenties at the London Stock Exchange and New York Stock Exchange. Furthermore, Weigt (2005) and Burhop (2006) documented that mean initial returns were around five percent at the Berlin Stock Exchange between the 1880s and World War I. In addition, even during speculative periods - e.g., during the early 1870s and during the late 1920s - mean initial returns were in the single digits. These findings indicate that the underpricing phenomenon changed substantially over time. Thus, the question arises whether underpricing theories can explain initial returns in different markets and periods.

Consequently, we confront the historical data with standard underpricing theories. More specifically, using an unique data set of 180 IPOs undertaken at the Berlin Stock Exchange between 1870 and 1896, we show that initial returns were zero during the hot market of the early 1870s and less than five percent thereafter; this confirms earlier findings by Weigt (2005) and Burhop (2006). Yet, our new data set is much more comprehensive. In particular, Weigt's (2005) data set is restricted to IPOs of long-living corporations, i.e., firms surviving from the IPO until 1913. Moreover, Weigt (2005) tested Rock’s (1986) classical underpricing theory, but cannot find a significant relationship between firm size, firm age and underpricing, i.e., she does not support Rock's theory. Nevertheless, Weigt (2005) is an important contribution, since she conducted the first and only test of underpricing theories using historical data on a global scale. Burhop (2006), on the other hand, has a randomly collected data set at hand, but did not exploit it to test underpricing theories; he focuses on the historical-institutional development of the German IPO market.

The current paper extends the available analyses substantially, confirms Weigts' (2005) conclusions, and yields five new results. First, we reject Rock's (1986) theory which states that asymmetric information among first investors is a reason for underpricing, i.e., information asymmetries among well-informed and badly informed investor groups were unimportant. Second, we do not find evidence in support of Carter and Manaster's (1990) hypothesis of a negative correlation between quality of the lead underwriter and initial returns. Third, signalling theories based on asymmetric information between issuer and first investor (e.g., Grinblatt and Hwang, 1989; Welch, 1989; Allen and Faulhaber, 1989) are rejected, i.e., we reject the hypothesis of costly 
underpricing in exchange for the smoother placement of seasoned equity offerings (SEOs). Fourth, stricter liability rules for incorporators and underwriters introduced in 1884 did not affect underpricing and we therefore cannot support Hughes and Thakor's (1992) litigation model of underpricing. Fifth, we detect a negative relationship between past market returns and underpricing, thereby contradicting studies using modern data (Loughran and Ritter, 2004; Lowry and Schwert, 2004). Finally, we find evidence that first investors readily accounted for potentially cash-flow relevant rules contained in the corporate charter. The risk of a transfer of cash-flow rights from the shareholders to the incorporators was punished with a substantial amount of money left on the table by the issuer. Therefore, we show that information was readily factored into equity prices and give support to the efficient market hypothesis put forward for the historical German stock market by Weigt (2005) and Baltzer (2006, 2007).

The remaining parts of the paper are organized as follows. Section II presents stylized facts about the development of the German stock market during the late $19^{\text {th }}$ and early $20^{\text {th }}$ century as well as details about the legal environment. Section III contains a selective review of underpricing theories and derives the estimation approach. The following Section IV describes the data; the econometric analysis is presented in Section V. The final Section VI concludes the paper.

\section{The German IPO market in the late $19^{\text {th }}$ century}

During the period of industrialisation, universal banks played a major role in the German economy: they facilitated its 'take-off', they provided loans to the modern industrial firms, and they monitored industrial corporations. Close bank-industry relationships ameliorated liquidity constraints of industrial firms and thereby made investment easier and supported industrial growth. ${ }^{1}$ Nevertheless, bank loans were only one way to ensure the financing of an industrial enterprise. Self-financing of investments using retained profits was significant in Imperial Germany. By far the most important source of capital was equity. Share capital accounted for more than half of the assets of Germany’s industrial corporations until World War I (Fohlin, 2007: 174).

Equity finance can be raised by firms via IPOs and thereafter via SEOs. In particular, a thriving market for IPOs enables corporations to tap new sources of finance. Moreover, by diversifying its sources of finance, a firm becomes independent of one key financier, e.g. a bank. From the financier's point of view, shares are more liquid than loans. Furthermore, holding a diversified portfolio of shares is less risky than holding a loan portfolio. Finally, a well-developed stock market can be - at least in the long run - a driving force behind economic growth.

As early as the 1840s, a stock market had emerged in Germany. However, until 1861 incorporation was heavily restricted by law in nearly all German states, and thus the number of listed corporations was rather small. The enactment of free incorporation during the 1860 s in some smaller German states culminated in the enactment of free incorporation in the North-German

1 The relevance of joint-stock credit banks for Germany's industrialisation is still debated. An excellent review of the literature is provided by Fohlin (2007). 
federation, including Prussia, in 1870. Finally, free incorporation became possible in all German states after the creation of the German Empire in $1871 .^{2}$

The following period of promotion (Gründerjahre) of the early 1870s was one of the key events of the economic history of the German Empire, with more than 400 IPOs within three years. The period of promotion was followed by the promotion crisis (Gründerkrise) between 1873 and 1878. During this period, 225 corporations were de-listed from the stock exchange, nearly exclusively caused by weak performance, and only 19 firms were newly listed on the market (Baltzer, 2007). Despite this substantial crisis, the 1870s saw a substantial net gain of listed corporations. Between 1879 and the enactment of Germany's first Stock Exchange Act in 1897, another 218 corporations went public, followed by 500 IPOs until World War I. Thus, 1,178 firms were newly listed at the German stock market within four decades, more than the 957 IPOs undertaken in Germany between 1949 and 2006 (Sapusek, 2000; Deutsche Börse). ${ }^{3}$

The booming IPO market of 1870-73 was caused by a set of factors, e.g., the introduction of free incorporation, the optimistic public mood after the formation of the German Empire in 1871, and the substantial indemnity paid by France after the Franco-Prussian War of 1870-71. It is very likely that only the combination of these factors caused the boom of the IPO market during the early 1870s (Baltzer, 2007). The promotion crisis, in turn, was related to the weak rights of first investors under the 1870 corporate law. As a result, the crisis was the key motivation for the major corporate law reform act in 1884 (Engel, 1875; Oechelhaeuser, 1876; Deutscher Reichstag, 1884; Burhop, 2004; Weigt, 2005; Baltzer, 2007).

In particular, the 1884 corporate law reform changed the rules of incorporation substantially. ${ }^{4}$ This set of rules was important for first investors, since other regulations were either voluntary like the listing rules of the stock exchanges - or enacted later - like the Stock Exchange Act in 1897. Before the enactment of free incorporation in 1870, most states - in particular Prussia audited incorporation. Only firms with a verifiable contribution to social welfare received the Royal concession necessary to incorporate. Moreover, joint-stock companies were supervised by civil servants. In general, only very respectable entrepreneurs incorporated and publicly listed companies were of a relatively high standard. ${ }^{5}$ Enactment of free incorporation implied that the audit of incorporation was handed over from a civil servant to a shareholder body, the supervisory board. However, the first supervisory board of a corporation was appointed by the incorporators, not by the first investors. Consequently, the incorporators audited the incorporation. This feature of the corporate law was changed in 1884. Since then, an audit committee of the chamber of commerce checked the incorporation and published a report (Ring, 1909; Wolff, 1915: 37,

2 The small city states Hamburg and Bremen never limited incorporation. Baden, Lübeck, Oldenburg, Saxony, and Württemberg introduced free incorporation in 1861 (Hopt, 1980).

3 All IPOs in the current sample are going-public of German firms.

$4 \quad$ Renaud (1875) and Gareis (1880) are textbook treatments of the corporate law. Lotz (1890), Pfleger and Gschwindt (1897), Thiwissen (1900), and Wolff (1915) review the working of the German IPO market during the late $19^{\text {th }}$ and early $20^{\text {th }}$ century.

5 Baltzer (2007) showed that the survival probabilities of joint-stock companies incorporated before 1870 was significantly larger than the survival probability of corporations founded after 1870. 
76). In addition, the complete corporate charter had to be published in the newspaper of the central government, the Reichsanzeiger, from 1884 onwards, whereas before only parts of the charter - the law did not prescribe which parts - had to be published, but without specifying the type of publication. After 1884, therefore potential investors could inspect the governance rules or the rules laid down for the distribution of profits more easily. This was an important piece of information, since many charters contained special rights for the incorporators (Gründerrechte), e.g., a profit share, membership in the supervisory board for several years, or subscription rights in case of an SEO. Most of these incorporators rights transferred cash-flow rights from the shareholders to the incorporators and are thus important for firm valuation.

Furthermore, liability of incorporators and underwriters were strengthened after 1884. First of all, the reform act constituted the legal person of the incorporator, an important pre-condition for any litigation. Moreover, the 1884 law prescribed that underwriters and their comrades (Gründergenossen) - e.g., the underwriter - were liable for a fair and truthful incorporation. Before 1884, the underwriter - for example - was only liable for explicit advice given to a certain investor, but not liable for information given in a prospectus or advertisements. After 1884, the incorporator as well as the underwriter were liable for such information, if the corporation was listed within two years after incorporation (Pfleger and Gschwindt, 1897: 126, 202; Thiwissen, 1900: 17, 43; Heim, 1910). ${ }^{6}$

Finally, the face value of shares was substantially increased to exclude the lower strata of the population from share ownership. Between 1870 and 1884, the minimum face value of a share was 300 Mark and only 40 percent of it had to paid-up before the IPO. ${ }^{7}$ Thus, the minimum investment to buy one share was 120 Mark, since offerings below par were interdicted. This compares to an annual per capita income of about 400 Mark during the period. The 1884 corporate law increased the minimum face value of a share to 1,000 Mark and an IPO was only possible for fully-paid up shares. Thus, the minimum investment increased by factor eight.

Jointly and severally, the 1884 corporate law reform act improved the information available to potential investors, it increased the liability of incorporators and of underwriters and it excluded lower strata of the population from a direct investment into shares. ${ }^{8}$ It is in question, if the reform addressed problems visible in first day returns before 1884 and if the reform achieved its targets.

In contrast to the regulation of IPOs, the issuing process remained similar over time. A group of investors - the promoters or incorporators - joined forces to establish a new joint stock company. In most cases, the incorporators bought an existing firm and changed its legal form. In some cases, however, only a business plan was presented to potential investors, and money was

6 The 1897 Stock Exchange Act extended the period of liability to five years after the IPO.

$7 \quad$ The owner of the share had the obligation to pay the call on demand.

8 Knowledge about first investors is nearly non-existing since there was no need to publish these data. It seems that even the smallest first investors invested a substantial amount of money. For example, Burhop (2004: 91, 98) shows that 76 (26) investors participated in the IPO of the Internationale Bank (Frankfurter Bankverein) and that the smallest investors bought shares with a face value of 30,000 (17,000) Mark. Pohl (1984: 42) listed the names of the 76 participants in the IPO of Deutsche Bank. 
collected to start this new business. Afterwards, the joint-stock company was incorporated and the shares offered to investors via an underwriter. ${ }^{9}$ The IPO itself was typically organized in three steps. First, the price for the issue and the risk-sharing were negotiated between issuer and underwriter. Then the appropriate offering price, the underwriting fee, and the distribution of the issue within an underwriting syndicate were negotiated. Third, the shares were actually sold either by the introduction to the market or by public subscription (Lotz, 1890: 41; Pfleger and Gschwindt, 1897: 108). ${ }^{10}$ In case of an introduction to the market, the underwriter applied for the admission of shares at the stock market. Afterwards, the underwriter sold the shares by and by at the stock market over a longer period. In the case of public subscription, the underwriter appealed to its customers in newspapers or by notifications to subscribe for the new shares at a fixed price within a certain period of time. After the period of subscription was over, the bank distributed the new shares to the customers (Thiwissen, 1900: 54; Wolff, 1915: 262). As an example, we include the prospectus of the IPO of “Actien-Gesellschaft Weser”, a large shipyard from Bremen. The prospectus states that the assets, staff, and technical knowledge of the privately-owned shipyard C. Waltjen \& Co. was acquired by the new joint-stock company and that the business should be continued. Moreover, the prospectus lists the names of the supervisory and executive board members and announced that one fifth of the share capital was on offer for public subscription at par value. This indicates that most shares were allocated in advance to blockholders. Potential investors could register their demand during a two day period at seven banks in six German cities. At the time of subscription, two percent of the potential investment had to be deposited at the underwriter. In case of oversubscription, the underwriters could arbitrarily allocate the shares to the investors. Seven days after the end of the subscription period, the shares were allocated to the investors.

\section{Theory and Econometrics}

Theoretical and empirical investigations of the underpricing phenomenon using modern data are in abundant supply (Ritter and Welch, 2002, review the literature). However, the most recent theories mostly require data, that are not readily observable by the econometrician and often unavailable in an historical setting. For example, the optimal IPO mechanism proposed by Biais et al. (2002) requires information about the supply and demand for a certain issue; the model proposed by Green (2007) requires knowledge about the distribution of the issue between institutional and retail investors. Given the limitations of the historical data, we focus on traditional theories. Nonetheless, we offer the most comprehensive study of the underpricing phenomenon

9 Our knowledge about the structure oft he underwriter market is very limited. At least 161 banks were underwriters between 1870 and 1896. The three largest underwriters - Preußische Bodencreditactienbank, S. Bleichröder, and Disconto-Gesellschaft - had a market share of slightly more than five percent each. The market share of the four large D-Banks - Deutsche Bank, Dresdner Bank, Disconto-Gesellschaft, and Darmstädter Bank - was about nine percent. Thus, the IPO market was quite dispersed and the large universal banks did not dominate the business.

10 The ability to reach retail customers was very important. Burhop (2004: 235-237) shows that even Germany's central government was not able to place government bonds without using the retail distribution network of banks. 
using historical data and thereby shed light on the structural (in-)stability of the underpricing phenomenon and its causes over time.

The classical paper by Rock (1986) suggests that asymmetric information about the quality of an IPO among different groups of investors can induce underpricing. ${ }^{11}$ If the demand from the group of informed investors is insufficient to buy the whole issue, uninformed investors will have to be attracted. Informed investors only buy high-quality issues, whereas uninformed investors buy a mix of high- and low-quality issues. Realizing this, uninformed investors have to be compensated by offering them all issues at a lower price.

Since the set of information available to specific investors is unobservable for the econometrician, tests of Rock's (1986) hypothesis add the assumption of a negative correlation between the size of an issue, the age of the newly listed corporation, and underpricing. The economic intuition behind this argument goes as follows: large and old firms produce more information than small and young firms. Therefore, more information is available for all investors, the problem of asymmetric information among different groups of investors becomes less important, and underpricing declines.

Generally, Rock’s hypothesis is supported using modern U.S. data (Kennedy et al., 2006; Michaely and Shaw, 1994). Yet, the evidence for the modern German market is not as clear-cut. On the one hand, Ljungqvist (1997) reports a positive and significant correlation between the size of an IPO and initial returns. On the other hand, Wasserfallen and Wittleder (1994) cannot find a statistically significant relationship. Turning to the available historical evidence, Weigt (2005: 154), using data for the Berlin Stock Exchange for the period 1882-1913, did not find a significant relationship between the size of the IPO, the age of the firm, and initial returns.

We employ several proxies for investor's information: The size of the new issue (i.e., number of shares offered times the offering price), the age of the corporation (i.e., number of months between incorporation as joint-stock company and going public), a dummy variable taking the value one if the firm existed as a commercial partnership before becoming a joint-stock company, and the minimum investment (i.e., the face value of one share times the offering price times the fraction of capital paid in). Rock's model predicts a significantly negative relationship between these four variables and underpricing.

The size of the issue and the age of the corporation are often employed proxies, whereas the two other variables need justification. If a firm existed as a commercial partnership before becoming a joint-stock company, the number of months since incorporation underestimates firm age. Thus, the dummy variable also captures information about firm age. The main concept underlying

11 Moral (1914: 47-49) speculates that asymmetric information between investors and underwriters and asymmetric information between different types of investors was relevant for underpricing. In particular, underwriters did not exactly know the market demand. Moreover, they wanted to keep their reputation and therefore offered shares at a price below the fair value. This was known at the stock market by some investors. These speculative investors subscribed the IPO. Then, speculative investors sold to the fundamentalist at the fair value in the secondary market. 
Rock's model is asymmetric information among different groups of investors. The higher the offering price of a share, the more wealth-constrained investors are excluded from the offering. Therefore, the remaining investors are more homogenous with respect to their wealth and this should reduce underpricing. Moreover, increasing the minimum face value of a share was a major component of the corporate law reform and we thereby test if this part of the reform influenced underpricing.

An important extension of Rock's (1986) hypothesis was proposed by Carter and Manaster (1990). They hypothesised that the quality of the lead underwriter is an important signal for investors. A high quality of the lead underwriter signals a high quality of the issue, a view shared by observes from the early $20^{\text {th }}$ century (Moral, 1914: 43; Jeidels, 1905: 128, 163). Thus, we expect a negative correlation between underpricing and the quality of the lead underwriter. Empirical evidence using U.S. data from the 1980s supported this hypothesis, whereas U.S. data from the 1990s did not. Therefore, the relationship between underwriter reputation and initial returns varied over time, but an investigation using historical data is still unavailable. We address this gap by including a measure of underwriter quality - the share of a bank in the Imperial Loan Syndicate (Reichsanleihenkonsortium) - into the regression. ${ }^{12}$

Another theoretical explanation of the underpricing phenomenon is based on asymmetric information between issuer and first investor. In particular, if the issuer knows more about the issue than the investor, a classic lemons problem emerges and the issuer should underprice the IPO to signal its quality. In particular, high-quality IPOs should use costly underpricing as a signal and they are more likely to take the money back from the table later on by having larger SEOs (Grinblatt and Hwang; Welch, 1989; Allen and Faulhaber, 1989). However, most empirical studies using modern U.S. and German data reject this signalling model (Kennedy et al., 2006; Michaely and Shaw, 1994; Wasserfallen and Wittleder, 1994). Studies based on historical data to test the time-stability of the phenomenon are unavailable. Our measure of SEO activity is the size of SEOs placed during five years after the IPO divided by the size of the IPO.

Furthermore, we incorporate the market sentiment hypothesis. Contemporaries hypothesised that the general economic and political climate, as well as the liquidity of the financial market, influenced the success of IPOs (Lotz, 1890: 44; Moral, 1914). Empirical studies using modern U.S. and German data also support a positive correlation between past performance of the stock market and initial returns (Loughran and Ritter, 2004; Lowry and Schwert, 2004; Ljungqvist, 1997). Moreover, Weigt (2005: 154) reports a positive correlation between the performance of a stock market index during the year preceding the IPO and initial returns for her sample of IPOs of long-living firms. We measure market performance by the return of the historical DAX-30 calculated by Ronge (2002) during the year preceding the IPO.

Moreover, we account for a special feature of the historical capital market, the incorporators' rights (Gründerrechte). They allocated cash-flow rights from the shareholders to the incorpora-

12 Only the most prestigious joint-stock credit banks and private banking houses were members of the consortium, and the membership was several times adjusted. See Reitmayer (1999). 
tors. This can affect underpricing since the extent of the cash-flow rights transfer is not known at the time of going public, thereby increasing the uncertainty regarding the fair firm value. For example, if incorporators have subscription rights in case of an SEO, the right only has a value if a SEO takes place. The value of the right then depends on the share price of the corporation at the time of issue, the fraction of shares allocated to the incorporators, and the subscription price of the incorporators. ${ }^{13}$ Thus, we expect a positive relationship between initial returns and the incorporators rights dummy as a compensation for higher uncertainty about the firm value and for the expected transfer of shareholder value to the incorporators.

Finally, we include a dummy variable taking the value one for all issues after the reform of the 1884 corporate law reform act. This dummy variable accounts for all changes of the post-reform period compared to the pre-reform period not covered by the above mentioned variables. For example, the 1884 corporate law increased the litigation risk for incorporators and underwriters in case of fraudulent IPOs. If litigation is possible, incorporators and underwriters would prefer positive initial returns since this indicates that the offering price was fair. However, the dummy variable also takes up all unobserved characteristics, whose impact on underpricing differs between the two sub-periods, e.g., differences in the quality of the firms going public or differences in the fraction of shares kept by the incorporators.

In summary, we estimate the following regression:

$$
\mathrm{IR}_{\mathrm{i}}=\mathrm{c}+\beta_{1} \mathrm{X}_{\mathrm{i}}+\beta_{2} \mathrm{DAX}_{\mathrm{i}}+\beta_{3} \mathrm{DAX}_{\mathrm{i}} \Delta 1884_{\mathrm{i}}+\beta_{4} \text { Change }_{\mathrm{i}}+\beta_{5} \text { Rights }_{\mathrm{i}}+\beta_{6} \Delta 1884_{\mathrm{i}}+\varepsilon
$$

The dependent variable $\mathrm{IR}_{\mathrm{i}}$ measures the 'first-day' return of IPO $\mathrm{i}$ in percentage points. The empirical investigation in Section V mainly employs the first return observed during the first five days after the official going public. This seems reasonable given the lower speed of information processing at historical stock markets. Moreover, we employ true first-day returns in a control regression, but did not find any difference in the results. The vector of $\mathrm{x}_{\mathrm{i}}$ of firm-specific explanatory variables accounts for observable characteristics attached to IPO i. In particular, $\mathrm{x}_{\mathrm{i}}$ includes the size, the age, the minimum investment, the quality of the lead underwriter, and the size of SEOs. Furthermore, we include the return of the DAX-30 blue chip index during the year preceding the IPO as a control variable. This control variable is also interacted with a dummy variable taking the value of one if the going public occurred after the corporate law reform. Moreover, the dummy variables Change ${ }_{i}$, Rights $s_{i}$, and $\Delta 1884_{i}$ take the value of one if the firm existed as a private firm before becoming a joint-stock company, if incorporators' rights were announced at the time of the IPO, and if the going public of firm i occurred after the corporate law reform. The results are presented in Section V. 


\section{Data}

A register of all IPOs undertaken by German corporations at German stock exchanges was constructed using various contemporary sources. In doing so, we were faced with the same information problems as contemporary investors. Our data set is therefore much more comprehensive for the period after 1884, since the availability of information improved significantly after the corporate law reform. Nevertheless, we cover a reasonable number of IPOs for the 1870s and we could not reject the hypothesis of randomness using a non-parametric randomisation test. ${ }^{14}$

For the period 1882-1896, the names of all newly listed corporations, their initial share capital, the name of the lead underwriter, the offering price, the first market price, and the date of going public were taken from Börsenenquetekommission (1892), Christians (1893), and Saling's Börsen-Jahrbuch (various years). ${ }^{15}$ For the period 1870-1881, the names of newly listed corporations and their year of going public were available from van der Borght (1883). Information on initial capital, the name of the lead underwriter, the offering price, and the date of going public were collected from Saling's Börsen-Jahrbuch (1875, 1882/ 83), Meyer (1873), and Berliner Börsenzeitung. The first market price was taken from Berliner Börsenzeitung. Supplementary information on the amount of SEOs undertaken during the first five years after the IPO and the face value of a share were collected from Saling's Börsen-Jahrbuch. Finally, using this source, two dummy variables were constructed. The first dummy variable takes the value of one if the IPO was the going public of a formerly privately-owned company. The second dummy variable indicates if the incorporator had preferential rights anchored in the corporate charter.

The register of German IPOs sold between 1870 and 1896 contains 647 firms: 489 for the period 1870-84, and 158 for the period 1884-96. Our final data set consists of 180 firms: 87 for the period 1870-84, and 93 for the period $1884-96 .{ }^{16}$ First, we removed 123 corporations from the register, since nearly no information was available for these IPOs. Most of these firms were never quoted in the Berliner Börsenzeitung. Therefore, it is very likely that the IPOs were undertaken at a regional stock exchange. ${ }^{17}$ Second, we excluded 87 IPOs for which the issuing price is not known. In most of these cases, shares were introduced to the market and sold by and by at the Berlin Stock Exchange. Third, 252 IPOs were removed from the sample since we could not observe the first market price within five days after the formal introduction at the Berlin Stock Exchange. ${ }^{18}$ The remaining sample includes 180 IPOs with a first-day market value of about 735

14 The results of the test are available upon request.

15 Saling's Börsen-Jahrbuch is a stock market annual, which was published annually from 1880 onwards. Moreover, it was irregularly published during the 1870s. For IPOs undertaken between 1892 and 1896, the first market price was in some cases derived from the Berliner Börsenzeitung, the leading financial daily.

This is a small number of observations compared to studies using modern U.S. data, which usually rely on several thousand observations. However, our sample has about the same size as the sample used by Ljungqvist (1997) to analyse the modern German IPO market.

17 The name of the corporation often reveals information about the location of the corporation. If a stock exchange existed in that location, it is reasonable to assume a listing at the regional stock exchange. Using IPOs with the first market price observed more than five days after the formal introduction to the market could result into less precise statistical results since we cannot adjust for market returns due to the unavailability of a daily stock market index. 
million Mark. ${ }^{19}$ The face value of the share capital in our sample equals about 40 percent of the face value of the shares of all firms going-public between 1870 and 1896.

Table 1 presents descriptive statistics of our sample. Initial returns were calculated as

$$
\mathrm{IR}=\left(\frac{\mathrm{p}_{\text {first }}-\mathrm{p}_{\text {offering }}}{\mathrm{P}_{\text {offering }}}\right) * 100 \text {. }
$$

The mean initial return between 1870 and 1896 was - compared to modern data - quite low and averaged only 2.5 percent. Initial returns were nearly zero before 1884 and about 4.4 percent during 1884-96. Moreover, only 58 percent of all issues had a positive first-day return during the pre-1884 era, whereas about 91 percent of the issues displayed positive initial returns during the post-reform era.

Some characteristics of the new issues were similar in both sub-periods: most firms were privately owned before the IPO - i.e., they only changed their legal form -, the fraction of corporations undertaking an SEO within five years after the IPO was around one quarter before and after 1884, and the mean size of an IPO was about four million Mark. ${ }^{20}$ Some characteristics, however, did change. After the reform, almost no corporation granted incorporators' rights, whereas half of the corporations did so before 1884. In addition, the minimum investment necessary to buy one share increased from 380 Mark to 1,352 Mark, i.e., from one time to more than three times the annual per capita income. Moreover, the period between incorporation and going public lengthened substantially from 15.1 to 25.4 months. Finally, the average reputation of the lead underwriter increased after 1884, but remained on a very low level: The large and well-known joint-stock credit banks as well as the leading private banking house were largely inactive on the IPO market. Nonetheless, comparing the point estimates of the variables outlined in Table 1 in view of their standard deviations suggest that the changes from the pre- to the post-1884 period was modest. Only the changes in the mean minimum investment and the granted of special cashflow (incorporators) rights changes substantially.

19 This compares to a stock market capitalisation of about 3.8 billion Mark in 1880 (van der Borght, 1883).

20 Moreover, the cumulative abnormal returns were most likely negative on average, before and after 1884. Our measure of CAR is the stock price at the end of the second year, plus dividend payments during this period, divided by the first market price and less the return of the historical DAX-30 over the same period. This shows a CAR of 15 percent for the pre-1884 issues, and a CAR of -11 percent of the post-1884 issues. 
Table 1: Descriptive Statistics

\begin{tabular}{lccc}
\hline & All observations & $\begin{array}{c}\text { pre-1884 } \\
\text { observations }\end{array}$ & $\begin{array}{c}\text { post-1884 } \\
\text { observations }\end{array}$ \\
\hline Mean initial return & $2.49 \%$ & $0.49 \%$ & $4.37 \%$ \\
Median initial return & $(9.14 \%)$ & $(11.92 \%)$ & $(4.73 \%)$ \\
Share of observations with ini- & $1.92 \%$ & $0.63 \%$ & $3.25 \%$ \\
tial return >0 & $75.0 \%$ & $57.5 \%$ & $91.4 \%$ \\
& 4,083 & 4,103 & 4,064 \\
IPO Size (in 1,000 Mark) & $(4,857)$ & $(5,426)$ & $(4,325)$ \\
Mean minimum investment (in & 883 & 380 & 1,352 \\
Mark) & $(753)$ & $(748)$ & $(347)$ \\
Share of firms changing legal & $70.6 \%$ & $60.9 \%$ & $79.6 \%$ \\
form & $(45.7 \%)$ & $(49.1 \%)$ & $(40.5 \%)$ \\
Share of corporations with in- & $25.6 \%$ & $49.4 \%$ & $3.2 \%$ \\
corporator's rights & $(43.7 \%)$ & $(50.3 \%)$ & $(17.8 \%)$ \\
Share of corporations with SEO & $23.9 \%$ & $23.0 \%$ & $24.7 \%$ \\
within 5 years after IPO & $(42.8 \%)$ & $(42.3 \%)$ & $(43.4 \%)$ \\
Average quality of the lead un- & $1.9 \%$ & $1.6 \%$ & $2.3 \%$ \\
derwriter & $(4.6 \%)$ & $(4.1 \%)$ & $(4.9 \%)$ \\
Time since incorporation (in & 20.4 & 15.1 & 25.4 \\
months) & $(73.8)$ & $(44.6)$ & $(93.2)$ \\
Number of observations & 180 & 87 & 93 \\
\hline Source: see Text Standard & & &
\end{tabular}

Source: see Text. Standard deviation in parentheses.

\section{Econometric analysis}

In this section, we test if the theories outlined in Section III explain underpricing on an historical stock market and we evaluate whether the 1884 corporate law reform had a measurable impact on initial returns. Tables 2 and 3 present our results. We start with two regressions using the whole sample and a dummy variable capturing possible shifts between the two sub-periods using standard OLS and weighted OLS (Table 2). Moreover, Table 3 presents two stability checks by restricting the sample to observations with a first-day return instead of using the first return during a five-day window after the official introduction to the market and by using a Tobit-model to account for censoring.

Turning first to Table 2, we note that the variables in the model are jointly significant and the model explains about 20 percent of the variance, a magnitude comparable to studies using data from the modern German capital market. Moreover, all variables accounting for problems of asymmetric information among different groups of investors are insignificant: size, age, minimum investment, and the fact that a firm already existed as a private enterprise before the going 
public did not matter for initial returns. ${ }^{21}$ Thus, we confirm the result presented by Weigt (2005: 154): She reported an insignificant relationship between size and age of an IPO, on the one hand, and underpricing at the Berlin Stock Exchange between 1882 and 1913, on the other.

Furthermore, we cannot support Carter and Manaster's (1990) theory of a significant role of underwriter quality on initial returns. The coefficient has the expected sign - high-quality underwriters signal the high-quality of an IPO and thereby reduce underpricing - but is insignificant. Moreover, we cannot support the various signalling theories put forward by Grinblatt and Hwang (1989), Welch (1989), and Allan and Faulhaber (1989). Signalling the high-quality of an IPO by the issuer to the investors by offering the new issue at a comparatively low price - resulting in high initial returns - and taking the money back from the table by large SEOs later on, seems not to work in $19^{\text {th }}$ century Germany, since the regression coefficient is insignificant.

From an economic and statistical point of view, we report a substantial influence of the past market performance on underpricing: A one percentage point increase of the DAX-30 blue chip index during the year preceding the IPO resulted into a decrease of underpricing of about 25 percentage points. Thus, the sign of the coefficient is in contrast to findings for modern markets (e.g., Loughran and Ritter, 2004; Lowry and Schwert, 2004; Ljungqvist, 1997). Yet, during the post-1884 period, the coefficient is still significantly negative, but the magnitude of the effect is now tiny.

Finally, and as expected, incorporators rights (i.e., the shift of cash-flow rights from shareholders to incorporators) have a significantly positive effect on initial returns. Firms having such a regulation in their charter left about 8.1 percentage points more money on the table than other firms. 
Dependent variable: Initial return in percentage points

\begin{tabular}{|c|c|c|c|c|}
\hline & \\
\hline & \multicolumn{2}{|c|}{ OLS } & \multicolumn{2}{|c|}{ weighted OLS } \\
\hline & Coefficient & $\mathrm{p}$-value & Coefficient & p-value \\
\hline Constant & 3.824 & 0.325 & 2.358 & 0.301 \\
\hline Size (in million Mark) & 0.029 & 0.846 & 0.243 & 0.011 \\
\hline Time since incorporation (in months) & -0.016 & 0.170 & -0.011 & 0.584 \\
\hline Minimum investment (in Mark) & 0.002 & 0.121 & 0.001 & 0.113 \\
\hline $\begin{array}{l}\text { Change in legal form dummy (equals one if } \\
\text { firms existed as a private firm before IPO) }\end{array}$ & -2.126 & 0.187 & -1.752 & 0.135 \\
\hline Underwriter reputation & -3.480 & 0.773 & -19.999 & 0.091 \\
\hline SEO in percent of IPO over five years & 0.470 & 0.554 & 1.401 & 0.094 \\
\hline DAX return, year preceding IPO & -25.016 & 0.017 & -16.269 & 0.001 \\
\hline DAX return, year preceding IPO*Post-1884 & 24.994 & 0.017 & 16.247 & 0.001 \\
\hline $\begin{array}{l}\text { Incorporator's rights dummy (equals one if } \\
\text { charter prescribed incorporator's rights) }\end{array}$ & 8.107 & 0.002 & 2.987 & 0.049 \\
\hline $\begin{array}{l}\text { Post- } 1884 \text { dummy (equals one if going pub- } \\
\text { lic was after corporate law reform) }\end{array}$ & -0.561 & 0.811 & 0.536 & 0.765 \\
\hline Number of observations & \multicolumn{2}{|c|}{180} & \multicolumn{2}{|c|}{180} \\
\hline F-Test (p-value) & \multicolumn{2}{|c|}{0.000} & \multicolumn{2}{|c|}{0.000} \\
\hline adjusted $\mathrm{R}^{2}$ & \multicolumn{2}{|c|}{0.197} & \multicolumn{2}{|c|}{0.253} \\
\hline
\end{tabular}

Method: OLS using corrected for heteroscedasticity in model 1; LS weighted by size in model 2. First price within five days after public offering.

Furthermore, the post-1884 dummy is insignificant. This indicates that the legal reform had no additional effects on underpricing or that the effects captured by this variable offset each other: the higher litigation risk of underwriters and incorporators should increase underpricing, whereas the broader scope and higher quality of information presented to investors should decrease underpricing.

Some noteworthy results emerge if we compare the standard OLS results with the weighted OLS results, using the size of an IPO as weight. Giving more weight to larger issues leads to weakly significant coefficients for underwriter reputation and SEO activity and both have the correct sign: high-quality underwriters reduced underpricing; larger issues tend to took the money back from the table using larger SEOs. Moreover, the coefficient measuring the impact of incorporators rights is now much smaller, indicating that incorporators rights were more important for smaller issues. However, these results depend on a special weighting procedure for the observations and should be interpreted with a grain of salt. 
Table 3: Initial returns, firm characteristics, and the legal reform - Stability tests

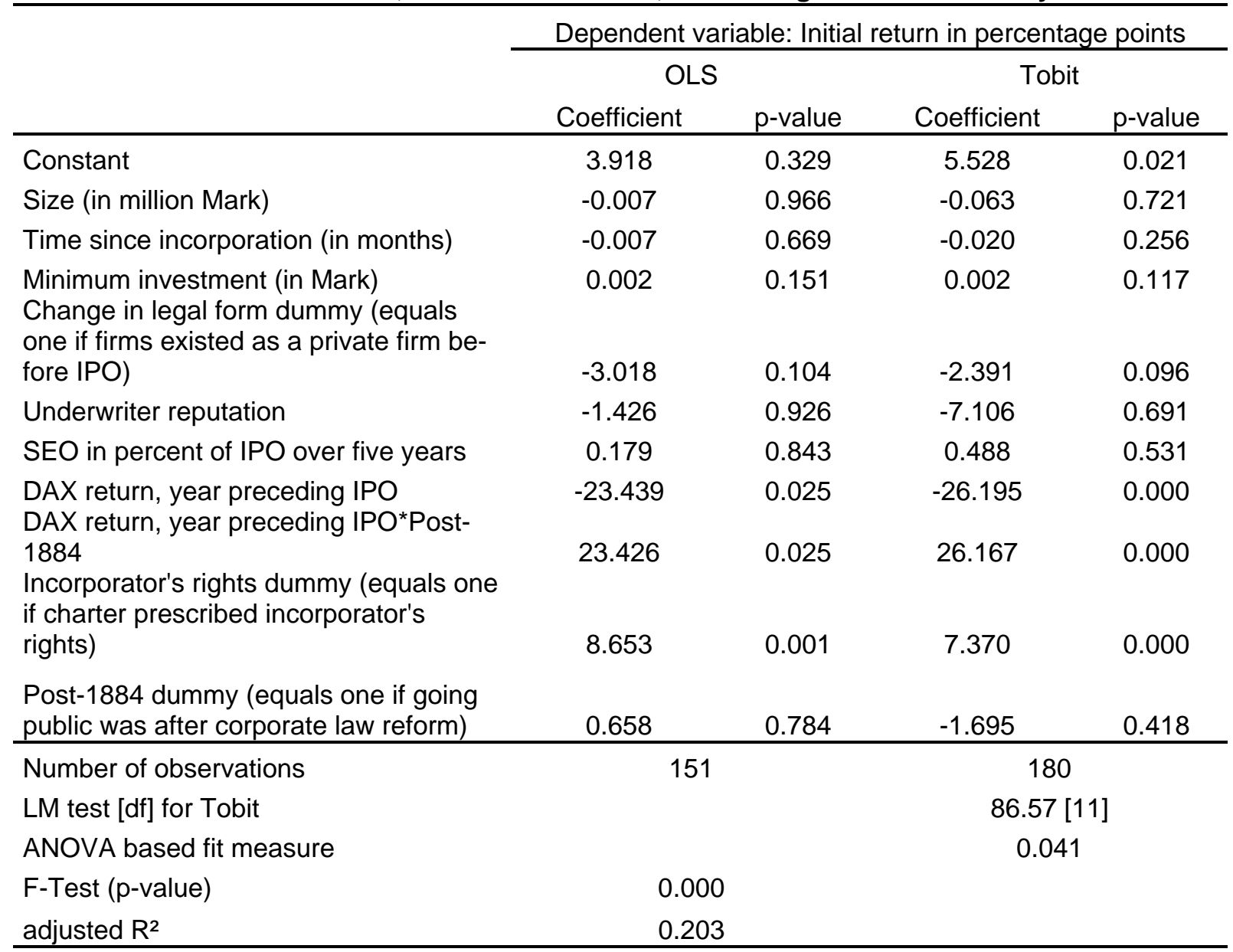

Method: Model 1-OLS using corrected for heteroscedasticity, with first price within five days after going public. only observations with first price at the first day. Model 2: Tobit regression, using all observations

Table 3 presents two additional stability tests. The regressions underlying the results presented in Table 2 rely on all IPOs with a first market price observed within five days after the official introduction to the stock market. The delay between the official introduction and the first quotation might be problematic, for example if trades occurred before the first price appeared in the newspaper. Therefore, we restrict the sample to the 151 (out of 180) cases with the first market price observed on the day of the official introduction to the market. Yet, this does neither affect the significance levels nor the magnitudes of the coefficients: Only the past return of the stock market index and the provision of incorporators rights in the corporate charter affect underpricing.

The second stability check employs a Tobit regression framework to account for possibly censored initial returns. The descriptive statistics presented in Table 1 show that about three quarters of all IPOs had a positive initial return. However, the specification test rejects the censoring hypothesis. Moreover, the coefficients as well as the magnitudes of the coefficients are similar to the standard OLS estimates. 


\section{Conclusion}

IPOs were the blood of early capital markets. Nonetheless, until the work by Weigt (2005), IPOs on the $19^{\text {th }}$ century German stock market were not subject to quantitative research. This paper contributes to this research by investigating the relationship between firm fundamentals, corporate law, and underpricing of initial public offerings at the Berlin Stock Exchange between 1870 and 1896. In particular, we evaluate potential problems of asymmetric information between issuers and investors as well as among different groups of investors and possible effects of institutions on underpricing.

It turns out that the pattern of initial returns changed substantially over time. More specifically, mean initial returns were zero during the early 1870s, whereas initial returns were positive on average from the 1880s onwards. Despite this 'obvious' change in underpricing, we fail to find a measurable effect of the corporate law reform enacted in 1884 to counter problems of incorporation and of initial public offerings. Moreover, the standard set of underpricing theories based on asymmetric information among investors (Rock, 1986), on asymmetric information between issuer and investor (Grinblatt and Hwang, 1989; Welch, 1989, Allan and Faulhaber, 1989), and on signalling via high-quality underwriters (Carter and Manaster, 1990) do not explain underpricing on historical markets. During the late $19^{\text {th }}$ century, underpricing was driven by the past performance of the general stock market and by cash-flow relevant provisions in corporate charters. The latter findings indicates that financial markets were efficient during period under investigation, since available information was rapidly reflected in market prices. Moreover, the finding that underwriter quality was unimportant for underpricing of IPOs sheds some doubt on the thesis that large joint-stock credit banks dominated the German financial business during the late $19^{\text {th }}$ century. 


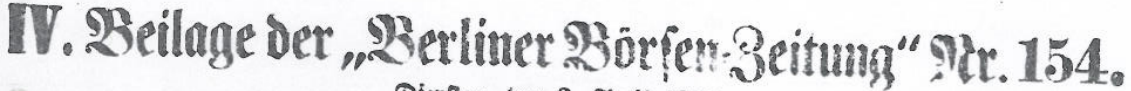 Diemftan, bes 3. Iuril 1872.}

\section{Actien-Gesellschaft, Weser" in Bremen.}

(Gesellschaft zum Bau elserner Schifle, Damplischiffe, Dampfmaschinen, Maschinentheile etc.)

[171750] (1)

Der Z Woek der Geaellsehaft int vaeh \$ 1 der S:atuten folgender:

and der Befrieb von Werften, Troekendocks, Keaselschmieden, Kisen-

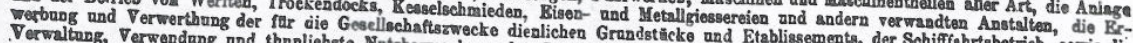
Verwaltung, Verwondung und thunliehste Nutzbarmachang des Gesellsebaftsvermbgens Etablissements, der Sohiffiahrtabetrieb, sowie die

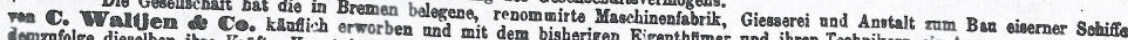
Das Grondeepital

\section{Ein und Einhalb Millionen Thaier,}

eingetheil in 2500 im 30 Thaler-FuSS,

A. G. Inoslo, Vorsitzender.

Cornolius Bechtel.

Tlehard Pritze.

Friedr. Der Aufsicht

Rud. Fenerstein, stellvertretender Vorsitzender.

I. Rnoop.

Joh. G. Lohmann

C. T. III elchers.

Geo. 8. Gruner.
Joh. Herm. Iiomann.

Carsten Waltjen.

D. :I. Wätjon.

Gustar Rohto.

Bezrgnehmend an voretebenden Prospect, offeriren wir hiermit von der obengenannten Summe von 1,500,000 Thelerm

300,000 Thaler im 30 Thaler-Fusse in 1500 Actien à 200 Thaler

mit vorläufig $10 \%$ Rinzahlung zum Pari-Courso. - Anmeldangen dsrauf werden am

Freitag, den 5. Ind Bommabend, den 6. April æogo.

in Bromen bei der Bremer Bank

in "bei der Bromor Filiale der Deutschen Bank, A.-G,

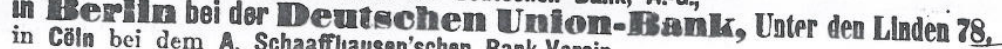

in Coln bei dem A. Schaaffiliausen'schen Bank-Verein

- in Crefold bei den Herren Gobr. Molenaar,

in Hamburg bei der Hamburger Filiale der Deutschen Bank, A.-G.

in den niblichen Geshor bei dem Herrn M. I. Fronsdorff, Provincial-Disconto-Gasellsehaft,

in den îblichen Geschäftsstunden ent gegengenommen.

Wh Cantion 20 deponiren, welche bei Lebernahme (Thir. 4. par Actie) oder in, der betreffandez Zeichenstelle genágenden, Werthpapieren Im Falle der Ueberzeichnaug bleibt Rednction ragascheine verrechnet oder surüekgegeben F'erden.

to aus Namen lauten, quittirt.

Rremen, Marn is72.

Das Consoptium. 


\section{References}

Allen, F., and Faulhaber, G.R. (1989)

Signalling by underpricing in the IPO market

Journal of Financial Economics, 23, 1989, 303-323

Baltzer, M. (2006)

Cross-listed stocks as information vehicle of speculation: Evidence from European crosslistings in the early 1870 s

European Review of Economic History, 10, 2006, 301-327

Baltzer, M. (2007)

Der Berliner Kapitalmarkt nach der Reichsgründung 1871

LIT Verlag, Münster

Biais, B., Bossaert, P., and Rochet, J.-C. (2002)

An optimal IPO mechanism

Review of Economic Studies, 69, 2002, 117-146

Börsenenquetekommission, Ed. (1892)

Die hauptsächlichen Börsen Deutschlands und des Auslandes 1882-1892

Reichsdruckerei, 1892

Burhop, C. (2004)

Die Kreditbanken in der Gründerzeit

Steiner Verlag, Wiesbaden

Burhop, C. (2006)

Die Technik des Gründungsgeschäfts in der Hochindustrialisierung

Bankhistorisches Archiv, 32, 2006, 91-112

Carter, R.B. and Manaster, S. (1990)

Initial public offerings and underwriter reputation

Journal of Finance, 45, 1990, 1045-1067

Chambers, D. and Dimson, E. (2008)

IPO underpricing over the very long run

Journal of Finance, forthcoming

Christians, W. (1893)

Die deutschen Emissionshäuser und ihre Emissionen in den Jahren 1886-1891

Schneider \& Co., Berlin

Derrien, F. and Kecskes, A. (2007)

The initial public offerings of listed firms

Journal of Finance, 62, 2007, 447-479

Deutscher Reichstag (1884)

Stenographische Berichte über die Verhandlungen des Deutschen Reichstages, 5. Legislaturperiode, 4. Session, 1884, Band 3, Anlage Nr. 21

Julius Sittenfeld, Berlin 
Engel, E. (1875)

Die erwerbsthätigen juristischen Personen im preußischen Staate, insbesondere die Actiengesellschaften

Zeitschrift des königlich-preußischen Statistischen Bureaus, 15, 1875, 449-536

Fohlin, C. (2007)

Finance capitalism and Germany's rise to industrial power

Cambridge University Press, Cambridge

Gareis, C. (1880)

Das deutsche Handelsrecht

Guttentag, Berlin

Green, R.C. (2007)

Presidential address: Issuers, underwriter syndicates, and aftermarket transparency

Journal of Finance, 62, 2007, 1529-1550

Grinblatt, M. / Hwang, C.Y. (1989)

Signalling and the pricing of new issues

Journal of Finance, 44, 1989, 393-420

Heim, R. (1910)

Die Rechtstellung des Emissionshauses bei der Einführung von Aktien in den Verkehr

R.G. Elwert'sche Verlagsbuchhandlung, Marburg 1910

Hopt, K.J. (1980)

Ideelle und wirtschaftliche Grundlagen der Aktien-, Bank- und Börsenrechtsentwicklung im 19. Jahrhundert

In: Coing, H. / Walter, W. (Ed.), Wissenschaft und Kodifikation des Privatrechts im 19. Jahrhundert, Band 5, Geld und Banken, Vittorio Klostermann, Frankfurt am Main, 1980, 128-168

Hughes, P.J. and Thakor, A.V. (1992)

Litigation risk, intermediation, and the underpricing of initial public offerings

Review of Financial Studies, 5, 1992, 709-742

Isobe, T., Takatoshi, K., and Kairys, J.P. (1998)

Underpricing, subsequent equity offerings and the long-run performance of Japanese IPOs

Asia-Pacific Financial Markets, 5, 1998, 237-259

Jeidels, O. (1905)

Das Verhältnis der deutschen Großbanken zur Industrie

Duncker \& Humblot, Leipzig

Kennedy, D.B., Sivakumar, R., and Vetzal, K.R. (2006)

The implications of IPO underpricing for the firm and insiders: Tests of asymmetric information theories

Journal of Empirical Finance, 13, 2006, 49-78

Ljungqvist, A.P. (1997)

Pricing initial public offerings: Further evidence from Germany

European Economic Review, 41, 1997, 1309-1320 
Loughran, T. and Ritter, J. (2004)

Why has IPO underpricing changed over time?

Financial Management, 33, 2004, 5-37

Lotz, W. (1890)

Die Technik des deutschen Emissionsgeschäfts: Anleihen, Konversionen und

Gründungen

Duncker \& Humblot, Leipzig

Lowry, M. and Schwert, G.W. (2004)

Is the IPO pricing mechanism efficient?

Journal of Financial Economics, 71, 2004, 3-26

Meyer, R. (1873)

Die Actien-Gesellschaften

Schindler, Berlin

Michaely, R. and Shaw, W.H. (1994)

The pricing of initial public offerings: Tests of adverse-selection and signalling theories Review of Financial Studies, 7, 1994, 279-319

Moral, F. (1914)

Aktienkapital und Aktien-Emissionskurs bei industriellen Unternehmungen

Duncker \& Humblot, München

Oechelhaeuser, W. (1876)

Die wirthschaftliche Krisis

Verlag von Julius Springer, Berlin

Pfleger, F.J. and Gschwindt, J. (1897)

Börsenreform in Deutschland

Cotta, Stuttgart

Pohl, M. (1984)

Ausgewählte Dokumente zur Geschichte der Deutschen Bank

In: Pohl, M. (1984), Beiträge zu Wirtschafts- und Währungsfragen und zur

Bankengeschichte, Main 1984, 35-55.

Reitmeyer, M. (1999)

Aus dem Zentrum in die Nische: Privatbanken und die Unterbringung deutscher Staatsanleihen 1867 bis 1914

Bankhistorisches Archiv, 25, 1999, 71-100

Renaud, A. (1875)

Das Recht der Actiengesellschaften

$2^{\text {th }}$ Edition, Tauchnitz, Leipzig

Ring, V. (1909)

Das Aktienrecht in Deutschland

In: Handwörterbuch der Staatswissenschaften, Vol. 1, $3^{\text {rd }}$ Edition, Jena 1909, 258-263

Ritter, J. R. and Welch, I. (2002)

A review of IPO activity, pricing, and allocations

Journal of Finance, 57, 2002, 1795-1828 
Rock, K. (1986)

Why new issues are underpriced

Journal of Financial Economics, 15, 1986, 187-212

Ronge, U. (2002)

Die langfristige Rendite deutscher Standardaktien

Peter Lang, Frankfurt am Main

Saling's Börsen-Jahrbuch

Haude \& Spener, Berlin

Sapusek, A. (2000)

Benchmark sensitivity of IPO long-run performance: An empirical study for Germany

Schmalenbach Business Review, 52, 2000, 374-405

Simon, C. J. (1989)

The effect of the 1933 securities act on investor information and the performance of new issues

American Economic Review, 79, 1989, 295-318

Thiwissen, A. (1900)

Das Emissionsgeschäft

Krefeld

Tinic, S. M. (1988)

Anatomy of initial public offerings of common stock

Journal of Finance, 43, 1988, 789-822

Van der Borght, R. (1883)

Statistische Studien über die Bewährung der Actiengesellschaften

Verlag von Gustav Fischer, Jena

Wasserfallen, W. / Wittleder, C. (1994)

Pricing initial public offerings: Evidence from Germany

European Economic Review, 38, 1994, 1505-1517

Welch, I. (1989)

Seasoned offerings, imitation costs, and the underpricing of initial public offerings

Journal of Finance, 44, 1989, 421-449

Weigt, A. (2005)

Der deutsche Kapitalmarkt vor dem Ersten Weltkrieg - Gründerboom, Gründerkrise und Effizienz des deutschen Aktienmarktes bis 1914

Fritz Knapp Verlag, Frankfurt am Main

Wolff, S. (1915)

Das Gründungsgeschäft im deutschen Bankgewerbe

Cotta’sche Verlagsbuchhandlung, Stuttgart 